\title{
Sublittoral meiofauna and macrofauna of Rocas Atoll (NE Brazil): indirect evidence of a topographically controlled front
}

\author{
S. A. Netto ${ }^{1,2, *}$, M. J. Attrill ${ }^{2}$, R. M. Warwick ${ }^{1}$ \\ ${ }^{1}$ Plymouth Marine Laboratory, Prospect Place, West Hoe, Plymouth PL1 3DH, United Kingdom \\ ${ }^{2}$ Benthic Ecology Research Group, Department of Biological Sciences, University of Plymouth, Drake Circus, \\ Plymouth PL4 8AA, United Kingdom
}

\begin{abstract}
Topographically controlled fronts are small-scale phenomena caused by the interaction between currents and complex reef topography, resulting in zones of convergence and eddies where debris and organisms are accumulated. Rocas is the only atoll in the South Atlantic $\left(3^{\circ} 51^{\prime} \mathrm{S}, 33^{\circ} 49^{\prime} \mathrm{W}\right)$ and it is constructed predominantly by coralline red algae, vermetid gastropods and encrusting foraminiferans. The structure of meiobenthic and macrobenthic communities, particularly nematodes and polychaetes, over the sublittoral carbonate deposits was examined during May 1996. Univariate and multivariate analyses showed a gradual change in the meiobenthic and macrobenthic community structure from the windward to the leeward side of Rocas Atoll, which was significantly correlated with the measured environmental variables. The characteristics of the carbonate deposits, ranging from coarse sands to medium well-sorted sand, and their enrichment process towards the leeward, as shown by the organic content, suggest a strong linkage with the hydrodynamic regime. Even though both components of the benthos are influenced by this hydrodynamic heterogeneity, the meiobenthic and macrobenthic fauna over the sublittoral area of Rocas Atoll are affected in different ways. Changes in the hydrodynamic regime promote a significant increase in diversity and density of the meiofauna, particularly nematodes, but the macrobenthos showed a more complex response, with a decreasing number of taxa and a variable abundance towards the leeward side. The results of this study suggest that the significant changes in the sediment characteristics and benthic community structure along the atoll may be a result of topographically controlled fronts.
\end{abstract}

KEY WORDS: Meiofauna - Macrofauna - Rocas Atoll · Community structure - Sublittoral - Front - Brazil

\section{INTRODUCTION}

Reef habitats are immediately perceived as diverse, abundant and productive. Whilst reef communities do represent one of the most biologically diverse systems (Sale 1980, Alongi 1989b, Sorokin 1993) many of the organisms contributing to the high species diversity of reefs constantly degrade them, converting massive reef structures to sand (Glynn 1997). The surrounding sand deposits, however, normally do not exhibit such high diversity communities as the reef itself (Guzman et al. 1987, Gourbault et al. 1995, Netto et al. 1999), but

\footnotetext{
•E-mail: sen@wpo.nerc.ac.uk
}

there is increasing evidence that a variety of reefassociated fauna may be strongly dependent on the peripheral benthos, foraging extensively over the carbonate sediment (Ambrose \& Anderson 1990, Frazer et al. 1991, Posey \& Ambrose 1994).

The majority of reef systems exist in conditions of permanent and intense hydrodynamic movement of water masses. Interactions between a complex relief, such as an offshore atoll, and oceanic currents generate secondary flows near the reef that result in eddies, upwellings and downwellings (Sorokin 1993). Rather than affecting only the water column processes, increasing plankton biomass and aggregating waterborne eggs and larvae, these small-scale topographically generated fronts influence the sediment composi- 
tion and deposition process (Wolanski \& Hamner 1988). As sediment properties have long been recognised as a major factor influencing benthic community structure (e.g. Warwick \& Buchanan 1970 , Jones 1984, Coull 1988), the topographically controlled fronts may be of particular relevance to the composition and abundance of soft-bottom reef communities.

Several studies detail the benthic community structure on reef-associated carbonate sediments (see review by Alongi $1989 b)$. With respect to atolls, although a number of studies have been carried out in the Pacific (Salvat \& Renaud-Mornant 1969, Villiers 1988, Intes \& Caillart 1994) and Indian Ocean (Rao \& Misra 1983, Narayanan \& Sivadas 1986, Naim 1988, Ansari et al. 1991), most of them have only focused on in-

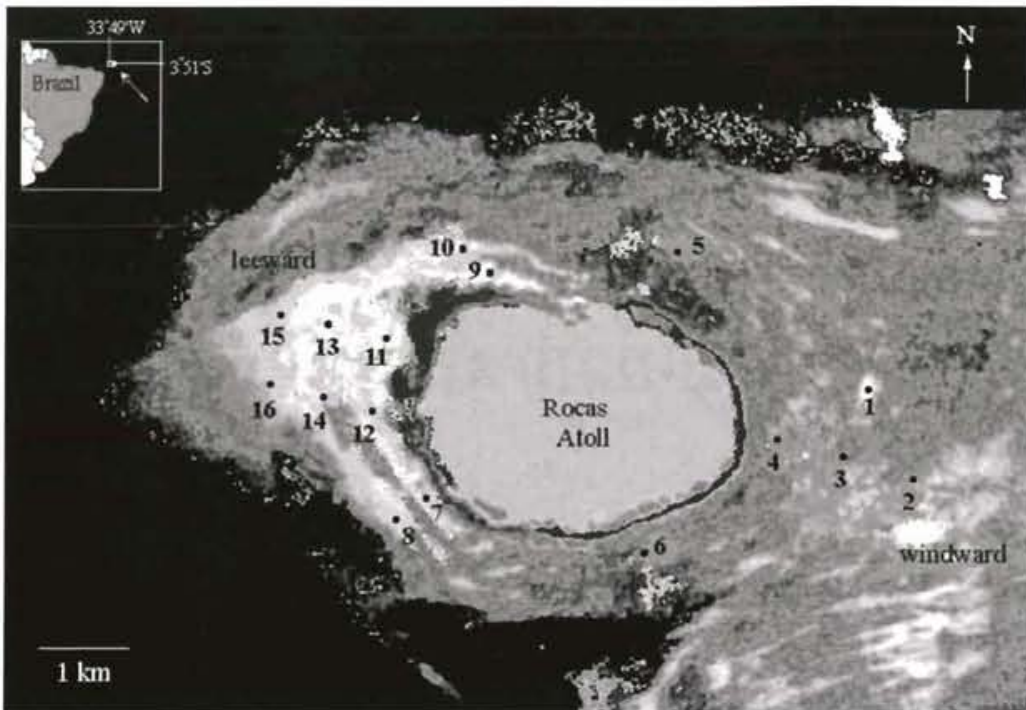

Fig. 1. TM-Landsat image of Rocas Atoll, NE Brazil, showing the sublittoral sampling sites (sand $=$ light patches)
Rocas is the only atoll in the South Atlantic and its reefs are mainly built by encrusting coralline red algae, vermetid gastropods, foraminiferans, molluscs and corals (Gherardi 1996). Studies of the island, located $266 \mathrm{~km}$ off the northeast Brazilian coast, are scarce: physical descriptions have been given by Ottman (1962) and Gherardi (1996); references to the occurrences of foraminiferans and mollusc species have been made by Ribas (1966), Tinoco (1967), Matthews (1970) and Rios (1985). Recently, Netto et al. (1999) showed that the patterns in community structure of meiofauna and macrofauna over sublittoral, tidal flat, reef pools and lagoon of Rocas are significantly different and related to the gradation in the physical environment of the atoll.

This paper reports on sublittoral meiobenthic and macrobenthic invertebrate response to a gradation in the physical environment of the offshore Rocas Atoll, NE Brazil, from the more wave-exposed windward area to the leeward. Changes in meiobenthic and macrobenthic community structure, particularly nematodes and polychaetes, are associated with the presence of topographically controlled fronts.

\section{MATERIAL AND METHODS}

Study site. Rocas Atoll ( $\left.3^{\circ} 51^{\prime} \mathrm{S}, 33^{\circ} 49^{\prime} \mathrm{W}\right)$ is an uninhabited biological reserve located $266 \mathrm{~km}$ off the northeast Brazilian coast (Fig. 1). The atoll reef rim ( $3.5 \mathrm{~km}$ long and $2.5 \mathrm{~km}$ wide), mainly built by encrusting coralline red algae, has a slightly elliptical shape and it is interrupted by passes in the N and NW. Gher- ardi (1996) provided a general description of geomorphologic features of the coralline reefs. Sublittoral carbonate sediments range from very coarse to fine sand and from very well to poorly sorted sand (Netto et al. 1999). Sands are patchily distributed (light patches in Fig. 1) and continuously transported towards the leeward side of the atoll, as observed by the satellite image showing the atoll and its shallow platform (Fig. 1). The South Equatorial Current and SE to E winds dominate the Rocas area. Currents can attain velocities up to $70 \mathrm{~cm} \mathrm{~s}^{-1}$ (Silveira et al. 1994) in the region and strong wind-generated waves are normally concentrated upon the eastern portion of the atoll (windward). The regional climate is tropical and dry: minimum air temperature is $26^{\circ} \mathrm{C}$ and annual average precipitation is $109 \mathrm{~mm}$ (Höflich 1984). Local tides have a semi-diurnal regime with maximum amplitudes of $3.8 \mathrm{~m}$ (Gherardi 1996).

Sampling. Sixteen stations, from windward to leeward, were sampled at depths between 5.2 and $24.1 \mathrm{~m}$ in May 1996 (Fig. 1). The patchy distribution of the sand and the variable thickness of sediment, mainly on the windward side, restricted the number of sampling sites surrounding the atoll. At each station, SCUBA divers collected 3 samples for meiofauna using a $2.5 \mathrm{~cm}$ diameter core tube pushed to a depth of $10 \mathrm{~cm}$, and 3 samples with a $10 \mathrm{~cm}$ diameter core tube to a depth of $10 \mathrm{~cm}$ were taken for macrofauna. On the surface, samples were immediately fixed in $4 \%$ buffered formalin. Superficial sediment for granulometric and organic content analyses was collected with a $5 \mathrm{~cm}$ core at each station. Meiofauna sample processing followed the procedures described in Somerfield \& 
Warwick (1996). Macrofauna samples were sieved on a $0.5 \mathrm{~mm}$ mesh, sorted, identified to the species or putative species and enumerated. The percentage of silt/clay in the sediment was determined by wet sieving using a $63 \mu \mathrm{m}$ sieve to separate the fine and sand fractions, which were then dried at $70^{\circ} \mathrm{C}$ and weighed. Sediment granulometry was determined by sieving dried samples. For the determination of organic content, sediment samples were dried at $70^{\circ} \mathrm{C}$ and then combusted for $1 \mathrm{~h}$ at $550^{\circ} \mathrm{C}$.

Data analyses. Univariate and non-parametric multivariate techniques used are described in Clarke \& Warwick (1994). For total meiofauna and macrofauna, univariate measures included only number of taxa and abundance because not all organisms were identified to the same taxonomic level. Univariate measures of sublittoral meiobenthic nematode and macrobenthic polychaete assemblages included: number of species $(S)$, total abundance $(N)$, Shannon-Wiener diversity indices calculated using $\log _{2}\left(H^{\prime}\right)$, Margalef's species richness (d) and evenness (Pielou's $J$ ). $S$ and $N$ were converted to approximate normality using a $\log (x+1)$ transformation. Differences in univariate measures between the stations were tested using 1-way ANOVA, and where results were significant ( $\mathrm{p}<0.05$ ), the Tukey multiple comparison tests were applied. Similarity matrices were constructed using Bray-Curtis similarity measure on fourth-root transformed faunal data, therefore reducing contributions to similarity by abundant species. The data were then ordinated by non-metric multidimensional scaling (Clarke 1993). The variability amongst replicate samples over the sublittoral area of the atoll was analysed using the multivariate relative dispersion measure, a procedure used by Warwick \& Clarke (1993) to examine an increase of variability between sample replicates with increased levels of perturbation. In order to analyse community pattern for evidence of common biotic structure, the abundance similarity matrices were compared using a Spearman rank correlation $(\rho)$ and significance determined using a permutation procedure (RELATE, Clarke \& Warwick 1994).

Environmental data (mean grain size, sorting, fine percentages, organic content and depth) were converted to approximate normality using a $\log (x+1)$ transformation and ordinated using a correlationbased principal component analysis (PCA). Although it is important to obtain information on replicate variability, averaging samples increases the signal-to-noise ratio for displaying patterns of change across sites in relation to an environmental gradient (Somerfield et al. 1995). For this reason, and because only 1 sample for analyses of abiotic data was taken, faunal abundances from 3 replicates at each station were averaged for analyses linking biotic and environmental data. The Bray-Curtis similarity matrices derived from averaged fourth-root transformed biotic data were compared with the environmental distance matrix using the procedure outlined above. The relationships between multivariate community structure and combinations of environmental variables were analysed using the BIOENV procedure (Clarke \& Ainsworth 1993) to define suites of variables that best explain the faunistic structure.

\section{RESULTS}

\section{Meiofauna}

The number of total meiobenthic taxa varied significantly over the sublittoral (Fig. 2a), being lower at stations located on the windward side (1, 4, 5 and 6$)$ and higher at Stns 14, 15 and 16, on the leeward side of the atoll (Tukey's HSD test, not shown). Mean population density of total meiofauna varied between 328 and 1476 ind. $10 \mathrm{~cm}^{-2}$. Meiofaunal densities were significantly higher at Stns 14 and 15 (Fig. 2b). Copepods and nematodes were the most abundant taxonomic groups, accounting for $78 \%$ of total meiofauna (50 and $27 \%$, respectively). The dominance of the 2 major meio-
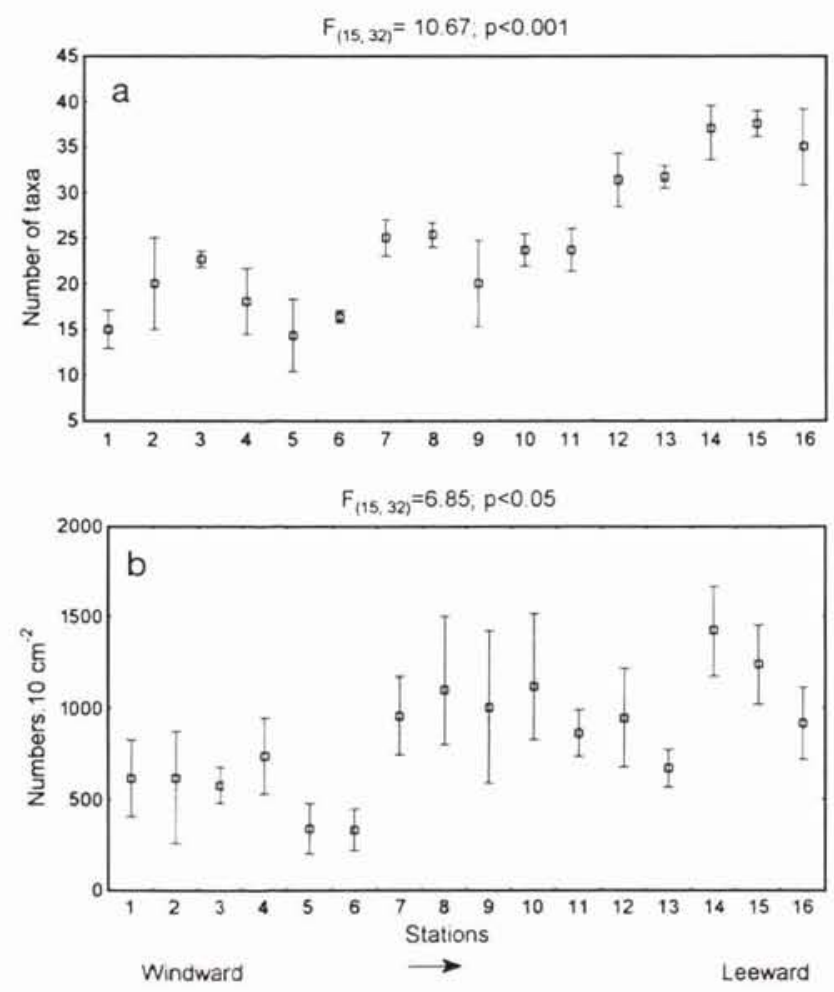

Fig. 2. Means and standard errors for (a) number of taxa and (b) density of total meiofauna 
benthic groups was variable along sublittoral stations of the atoll, where the copepods were the dominant group at the windward stations, and the nematodes were more abundant at the leeward stations. The next numerically important meiobenthic groups, such as Ostracoda ( $9 \%$ of total meiofauna abundance), Polychaeta $(7 \%)$ and Acari $(2 \%)$, did not show a clear tendency from the windward to the leeward side of the atoll.

A total of 89 putative nematode species was recorded and Epsilonema sp. 1 and Perepsilonema sp. 1 (Epsilonematidae) were the most abundant forms. All univariate measures of nematode community structure varied significantly between the sublittoral stations (Table 1). Tukey's HSD post hoc comparisons showed that the number of species, abundance, diversity and species richness were significantly higher at stations located on the leeward side of the atoll (Fig. 3). Analyses of nematode feeding types in the sublittoral carbonate sands, according to Wieser's (1953) classification, did not show a clear dominance of one feeding type (Fig. 4). However, whilst the percentage of relative abundance of selective deposit feeders (Fig. 4: 1A) was significantly lower at stations located on the leeward side (Fig. 4), the abundance of epigrowth or
Table 1. $F$ ratios and significance levels $\left(F_{15,32}\right)$ from 1-way ANOVA tests for differences in some univariate measures derived from meiofauna and macrofauna community structure between sublittoral stations of Rocas Atoll

\begin{tabular}{|llcccc|}
\hline \multirow{2}{*}{$\begin{array}{l}\text { Univariate } \\
\text { measure }\end{array}$} & \multicolumn{2}{c}{ Nematodes } & \multicolumn{2}{c|}{ Polychaetes } \\
& $F$ & $\mathrm{p}$ & $F$ & $\mathrm{p}$ \\
\hline Number of species $(S)$ & 8.03 & 0.001 & 4.97 & 0.001 \\
Abundance $(N)$ & 5.1 & 0.001 & 3.98 & 0.006 \\
Diversity $\left(H^{\prime}\right)$ & 5.1 & 0.006 & 4.7 & 0.006 \\
Richness $(d)$ & 6.36 & 0.003 & 4.8 & 0.005 \\
Evenness $(J)$ & 4.55 & 0.001 & 4.7 & 0.008 \\
\hline
\end{tabular}

diatom feeders (Fig. 4: 2A) displayed an opposite trend, increasing towards the leeward side of the atoll. Non-selective deposit feeder (Fig. 4: 1B) and predator/omnivore (Fig. 4: 2B) groups did not show a clear distribution pattern along the sublittoral stations, always representing less than $25 \%$ of total abundance (Fig. 4).

MDS ordination of fourth-root transformed meiofauna and nematode abundance data (Fig. 5a,b) clearly showed that the stations are distributed along a gradient, from the more wave-exposed sites (Stns 1, 2, 3 and 4) to the more leeward sites (Stns 14, 15 and 16).
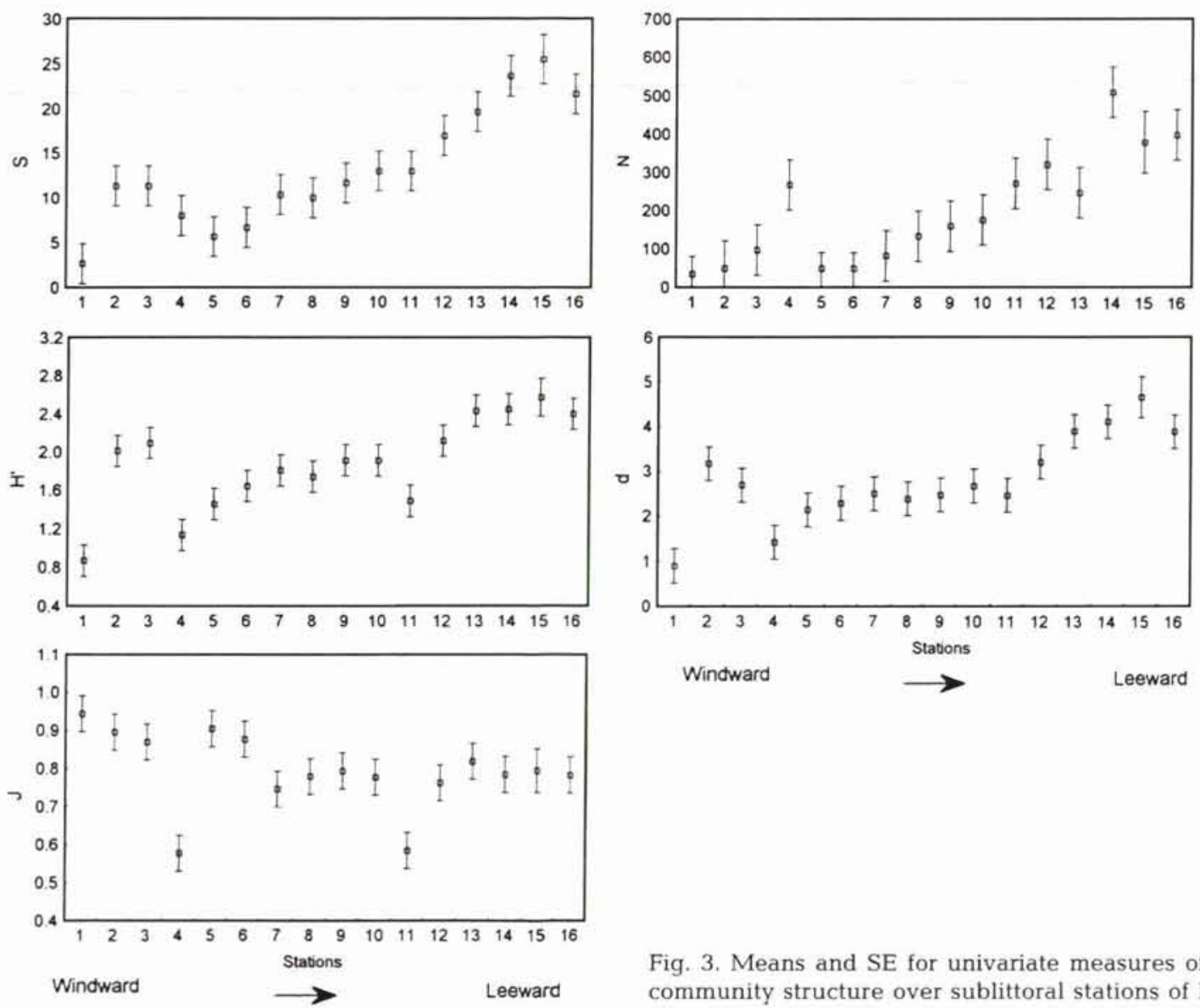

Fig. 3. Means and SE for univariate measures of nematode community structure over sublittoral stations of Rocas Atoll 

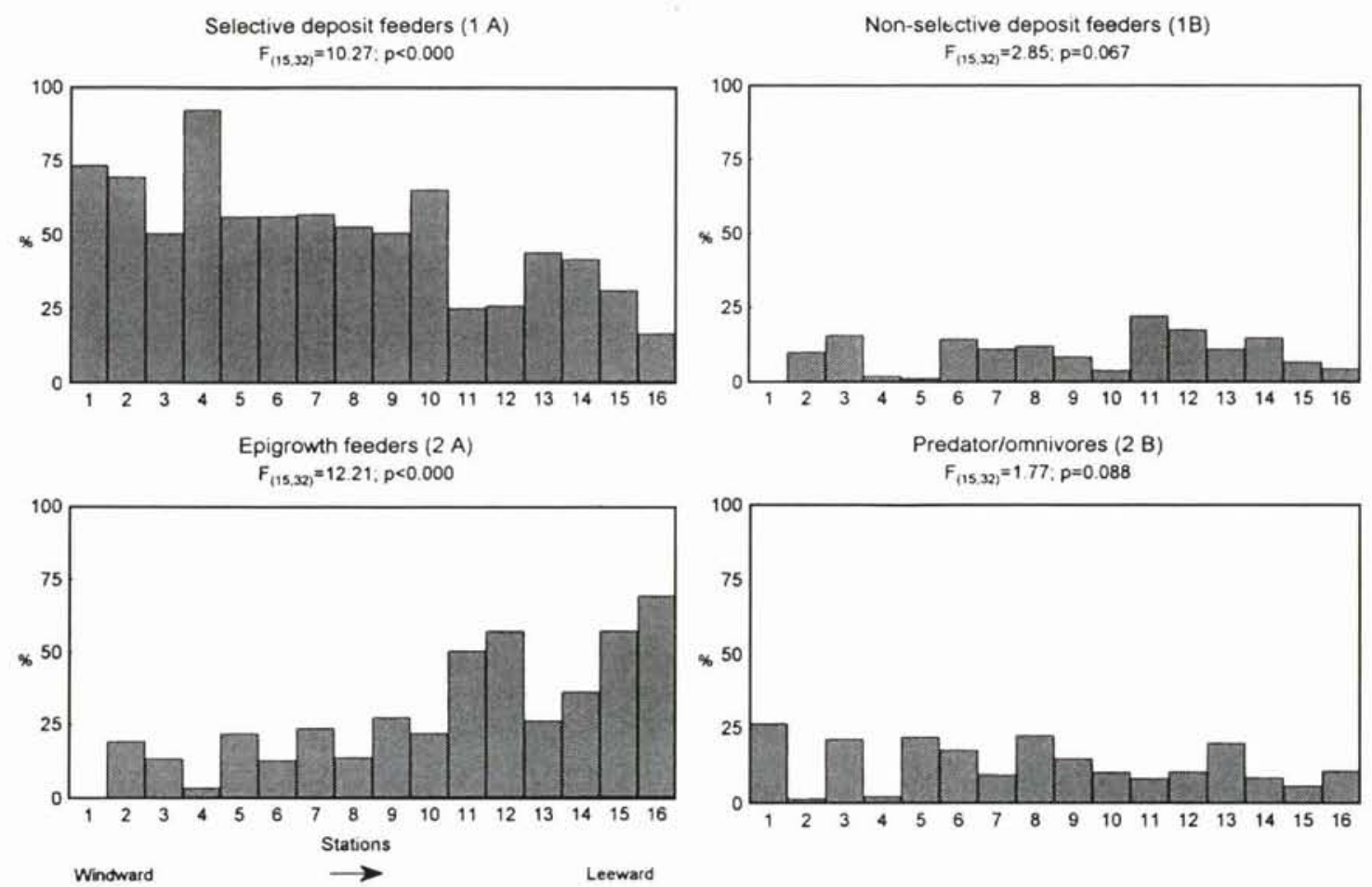

Fig 4. Distribution of nematode feeding types (1A, 1B, 2A and $2 \mathrm{~B})$ as mean percentage of abundance, $F$ ratios and significance level from 1-way ANOVA tests for differences between sublittoral stations of Rocas Atoll

Both MDS plots also indicate a wide spread of replicate samples on the windward side of the atoll when compared to leeward. Sample relative dispersion values (Fig. 5c), which indicate the variability in meiofauna and nematode multivariate structures within each station, confirmed the decrease in the variability across the atoll.

\section{Macrofauna}

The total number of macrobenthic taxa decreased from the windward to the leeward stations (Fig. 6a). Tukey's HSD post hoc comparisons showed that the number of macrofauna taxa was significantly higher at Stns 2 and 3, at the windward, and higher at Stns 13 to 16. Average densities of total macrobenthic invertebrates ranged from 4904 to 25402 ind. $\mathrm{m}^{-2}$, and did not show a clear trend over the gradient (Fig. 6a). Macrobenthic density was significantly higher at Stn 16 . Polychaetes were the dominant taxonomic group at all stations, representing $61 \%$ of the total macrofauna. Oligochaetes and nematodes were numerically the next most important groups accounting, respectively, for 14 and $13 \%$ of the macrofauna. Densities of crustaceans and other groups, such as bivalves and gastropods, were low and decreased towards the leeward side of the island.
A total of 38 species ( 22 families) of polychaetes were recorded in the sublittoral sands of Rocas. Eteone heteropoda, Saccocirrus papilocerus and Macrochaeta clavicornis were numerically dominant, representing more than $40 \%$ of the total. Univariate measures derived from polychaete data varied significantly across the stations (Table 1). However they did not show a very clear pattern of change from windward to leeward stations (Fig. 7).

Ordination of fourth-root transformed macrofauna and polychaete abundance data (Fig. 8a,b) showed changes in community structure along a gradient, from windward to leeward stations. Replicate variability for macrofauna and polychaete data, as shown by sample relative dispersion (Fig. 8c) did not indicate a clear pattern of change across the sublittoral stations.

The comparison between the benthic communities of sublittoral sediments (Table 2) showed that all similarity matrices were significantly correlated $(\mathrm{p}<0.001)$. The highest correlation was between macrofauna and polychaetes, indicating the importance of this group in structuring the macrobenthos.

\section{Environmental variables}

Ordination by principal component analysis (Fig. 9) of the environmental data clearly showed that stations were distributed along a marked gradient from wind- 
ward to leeward of the atoll. Components 1 and 2 accounted for $77 \%$ of the total variance (PC1 $=43 \%$ and $\mathrm{PC} 2=34 \%$ ). Carbonate sediments ranged from very coarse, moderately sorted sands at the windward stations (1 to 5) to medium, well-sorted sand in the leeward area (Stns 12 to 15, Fig. 10). Fine percentages
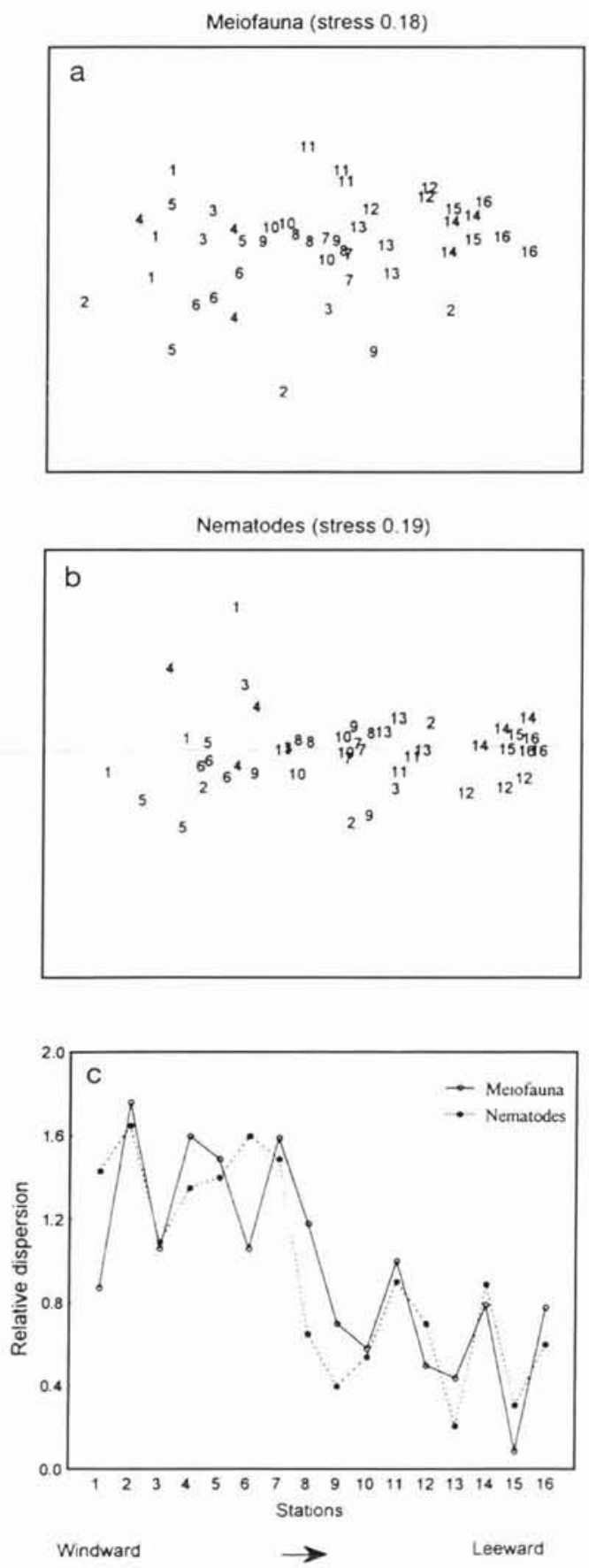

Fig. 5. MDS ordinations from transformed abundances of (a) meiofauna and (b) nematode, and (c) variability among replicate samples at stations over the sublittoral area of the atoll

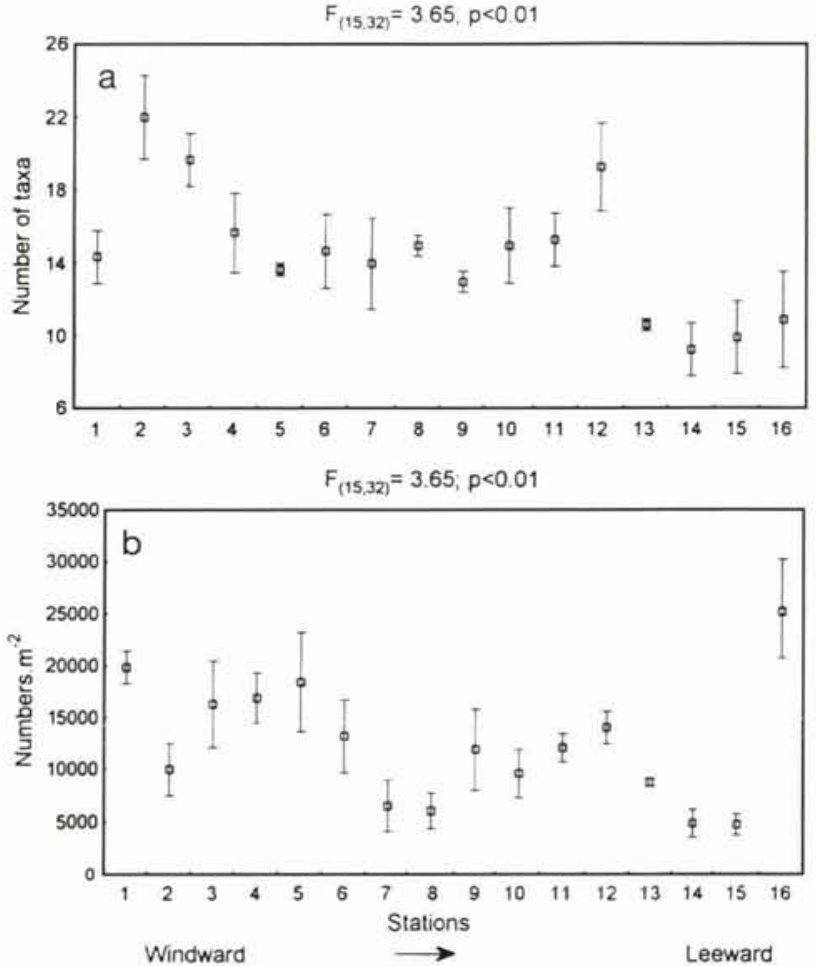

Fig. 6. Means and SE for (a) number of taxa and (b) density of total macrofauna

and total organic content, never higher than $2.81 \%$, also exhibited a tendency to increase their values towards the leeward portion of the atoll (Fig. 10). MDS ordinations, derived from similarity matrices of averaged transformed biotic abundances, all indicated that the distribution of the benthic community also occurred along a gradient (Fig. 9).

Spearman rank correlations between the Euclidean distance matrix from abiotic data and similarity matrices from biotic data presented in Fig. 9 were all significant $(\mathrm{p}<0.001$ ). The results of BIO-ENV analyses (Table 3 ) showed a similar result for the meiofauna and nematodes, in which the highest correlation value $(0.62)$ occurred with mean grain size and sorting. Fourth-root transformed macrofauna and polychaete abundance data showed the highest correlations $(0.67$ and 0.72 , respectively) with the same variables as meiofauna and nematodes, with the addition of fine percentages (Table 3 ).

\section{DISCUSSION}

The results of univariate and multivariate analyses showed a gradual change in the meiobenthic and macrobenthic community structure from the windward to the leeward side of Rocas Atoll, which were signifi- 

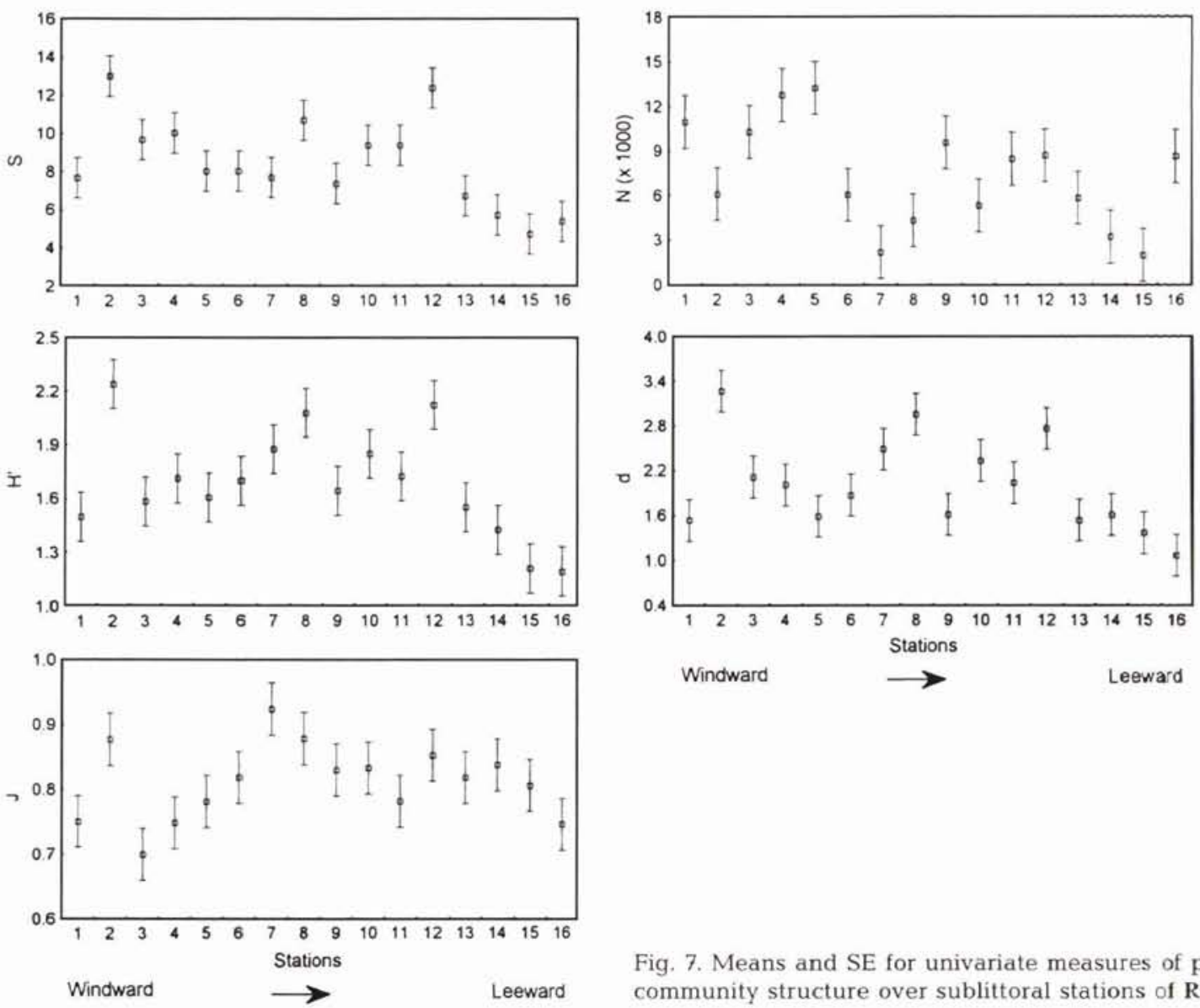

Fig. 7. Means and SE for univariate measures of pollychaete community structure over sublittoral stations of Roces Atoll


Fig. 8. MDS ordinations from transformed abundances of (a) macrofauna and (b) polychaetes, and (c) variability among replicate samples at stations over the sublittoral area of the atoll 
Table 2. Pairwise Spearman rank correlation between similarity matrices derived from fourth-root transformed biotic abundance data. All correlations are significant at $p<0.001$

\begin{tabular}{|lccc|}
\hline & Meiofauna & Nematodes & Macrofauna \\
\hline Nematodes & 0.777 & & \\
Macrofauna & 0.425 & 0.452 & \\
Polychaetes & 0.429 & 0.429 & 0.857 \\
\hline
\end{tabular}

cantly correlated with the measured environmental variables. The characteristics of the carbonate deposits, ranging from coarse, poorly sorted sands to medium, well-sorted sand, and the enrichment process towards the leeward, as shown by the organic content gradient, suggest a strong linkage with the hydrodynamic regime. Even though both components of the benthos are affected by this hydrodynamic heterogeneity, the mechanics of this influence on the meiobenthic and macrobenthic components over the sublittoral area of Rocas Atoll clearly differ.
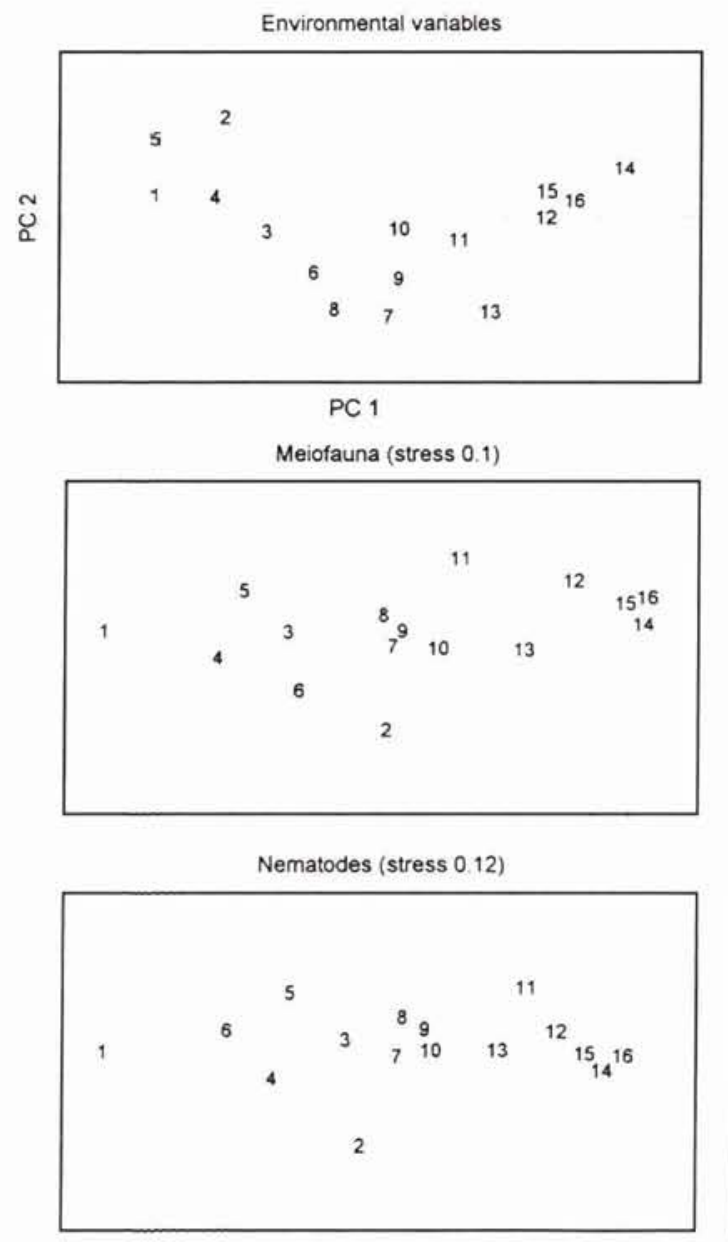

The changes in the level of stress to which the Rocas fauna is subjected could be detected by the variation in the relative dispersion values of the samples. Both meiobenthic and nematode replicate samples clearly exhibit higher dispersion values in the more waveexposed sites, decreasing towards the leeward side of the atoll. However, the variability amongst macrobenthic and polychaete data sets did not exhibit a clear trend, although relative dispersion values were generally higher than the meiofauna over the sublittoral station. Warwick \& Clarke (1993) suggested that there are 2 potential sources of increased variability among replicate samples: increase in the variability of abundances of the same set of species and changes in species identity. Using multivariate analyses (MDS and index of multivariate dispersion), which exploit both sources of variability, they detected an increase of variability among replicate benthic samples with increase in stress levels. The different responses of the components of the benthos to a similar environmental variability at Rocas Atoll are probably related to the different mechanisms for diversity maintenance between meiofauna and macrofauna. Whilst the meiofauna present a more specialised feeding behaviour and partitioning of food resources, the macrofauna are relatively unselective in their food requirements and may depend on spatial partitioning of the habitat (Whitlatch 1980, Warwick 1984). Thus, the high variability of the macrofauna over the sublittoral area suggests that they are more likely to be affected by the

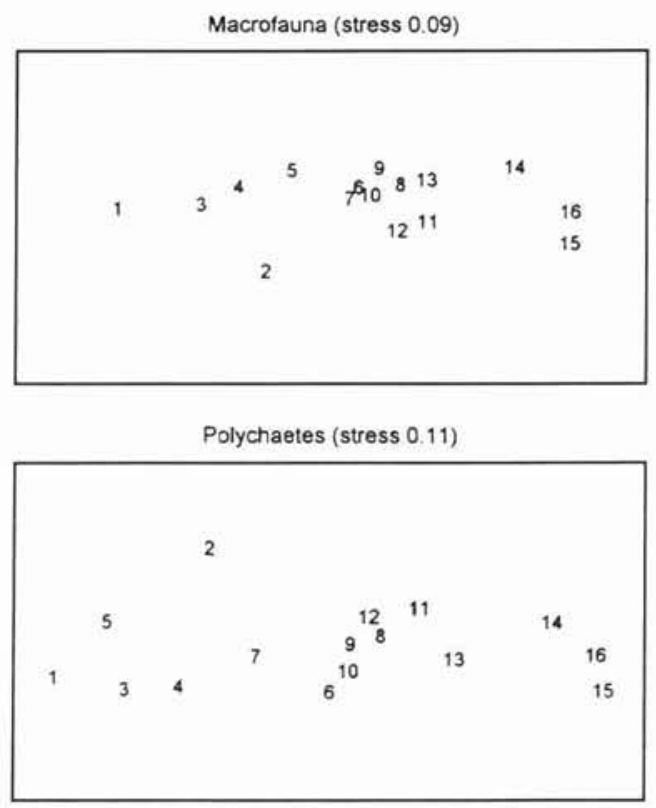

Fig. 9. Ordinations by PCA of environmental variables, and by MDS of averaged abundances from sublittoral stations 

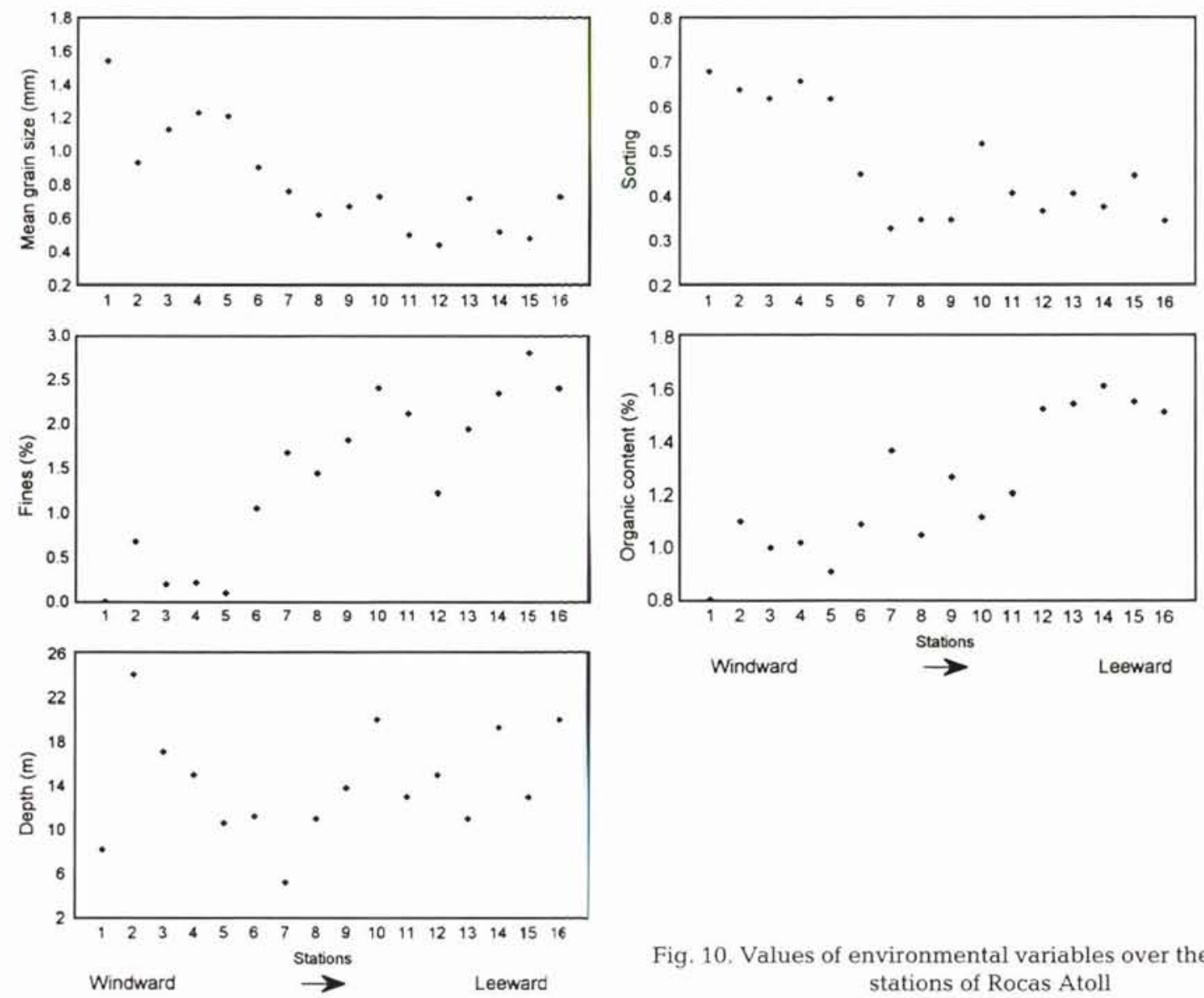

Fig. 10. Values of environmental variables over the sublittoral stations of Rocas Atoll

local physical instability of the sediment than the meiobenthic forms. This differential effect of physical stress on the components of benthos closely corroborates previous observations by McLachlan (1983) and Warwick et al. (1990).

The average macrofauna density in the sublittoral area of Rocas is similar to those recorded from other tropical sand habitats (Alongi 1989b). However, the fauna clearly possesses characteristics that reflect a harsh environmental regime. The macrobenthos is largely dominated $(88 \%)$ by small surface-dwelling polychaetes, oligochaetes and large nematodes. Abundance of crustaceans, bivalves, gastropods and other

groups, such as echinoderms, were very low and relatively important only in some windward sites. The relatively small size of the fauna and their surfacedwelling opportunistic nature probably indicate a low detrital input and may suggest that the macrobenthos could respond rapidly to the local physical instability. These characteristics of the sublittoral macrobenthic forms at Rocas are similar to those described in other shallow subtropical or tropical continental shelves subjected to erratic and low nutrient inputs and physical stress (Yingst \& Rhoads 1985, Alongi 1989a).

In contrast to the variable pattern demonstrated by the macrofauna, the meiofauna clearly showed an in-

Table 3. Summary results from BIO-ENV. Combinations of environmental variables yielding the best match of biotic and abiotic similarity matrices, as measured by weighted Spearman rank correlation $\left(\rho_{\mathrm{w}}\right)$

\begin{tabular}{|c|c|c|c|c|}
\hline & Meiofauna & Nernatode & Macrofauna & Polychaete \\
\hline Best variable & $\begin{array}{l}\text { Mean grain size } \\
\text { Sorting }\end{array}$ & $\begin{array}{l}\text { Mean grain size } \\
\text { Sorting }\end{array}$ & $\begin{array}{l}\text { Mean grain size } \\
\text { Sorting } \\
\% \text { fines }\end{array}$ & $\begin{array}{l}\text { Mean grain size } \\
\text { Sorting } \\
\% \text { fines }\end{array}$ \\
\hline$\rho_{w}$ & 0.62 & 0.62 & 0.67 & 0.72 \\
\hline
\end{tabular}


crease in the number of species and abundance towards the leeward side of the atoll. The progressive change in the meiobenthic community structure is particularly evident for the nematodes. Whilst windgenerated currents and waves may prevent the deposition of organic particles in the windward sediments of the atoll, as well as the establishment of a richer meiobenthic assemblage, there is a clear increase of the sediment organic matter value towards the leeward side. The increase of productivity around oceanic islands, specifically on the leeward side, has been observed by a number of authors (e.g. Alldredge \& Hamner 1980, Charpy-Roubaud \& Charpy 1994). Wolanski \& Hamner (1988) suggested that such enhancement of organism density is mainly caused by topographically controlled fronts, a small-scale interaction between currents, reef topography and island wake resulting in zones of convergence and eddies where debris and organisms accumulate. This aggregation affects the distribution of sediments, waterborne eggs, larvae, and phyto- and zooplankton, consequently influencing the distribution and density of benthic assemblages (Borgne et al. 1985, HernándezLeón 1991). Meiobenthic communities are known to be subjected to the same erosion/suspension processes that act on sediments (Palmer \& Gust 1985, Gamenick \& Giere 1994). Thus, it may be possible that the significantly higher density and diversity of meiofauna and nematodes towards the leeward side of the Rocas Atoll may be a result of 2 main processes caused by the topographically controlled fronts: the passive transport of the fauna, and active aggregation in areas of more abundant and enriched food particles.

Tietjen (1991), studying the ecology of nematodes from the Great Barrier Reef, suggested that assemblages from shallow carbonate sediments are particularly dominated by species belonging to the same families and genera. Species which dominated the sublittoral carbonate sands from the Red Sea (Grelet 1984), Guadaloupe (Boucher \& Gourbault 1990) and off North Carolina (Tietjen 1971) were those belonging to the families Desmodoridae, Chromadoridae and Xyalidae, and to a lesser extent Cyatholaimidae, Linhomoeidae, Oncholaimidae and Comesomatidae. However, Netto et al. (1999) showed that the structure of nematode assemblages differs significantly between the habitats of the Rocas Atoll. In the specific case of the shallow sublittoral sediments, they are largely dominated by species belonging to Epsilonematidae, although Draconematidae, Chromadoridae and Desmodoridae are also important. Moreover, as evidenced by the MDS ordination, the area is not homogeneous and there is a gradual change in the structure of the local nematode assemblages; Draconematidae are more abundant on the more wave-exposed windward side whereas Chro- madoridae and Desmodoridae are more abundant to the leeward of the atoll. Although there may be some similarities between nematode assemblages from carbonate sands, this similarity is more likely due to the high hydrodynamic conditions which these areas are subjected to rather than the nature of the sediment itself. Similar patterns of dominance in non-carbonate sandy bottoms were recorded by Ward (1975) and Willems et al. (1982).

The absence of a dominant nematode feeding type in the sublittoral area of the atoll, previously described by Netto et al. (1999), conceals the gradual and significant shift in the abundance of selective deposit feeders and epigrowth feeders from the windward to the leeward side of Rocas. Whilst the densities of selective deposit feeders significantly decreased over the sites, the epigrowth or diatom feeders showed an inverse pattern, increasing towards the leeward. The co-dominance by these 2 trophic types probably reflects, on one hand, the availability of the 2 major sources of food and, on the other, the hydrodynamic conditions of the area. The abundance of microbial populations in carbonate sands is known to be heavily dependent upon the density of corals (Sorokin 1993): the largest microbial biomass was found in sands with a rich or medium coral cover, and the smaller in sands of corallinae algae reefs such as Rocas Atoll. High densities of selective deposit feeders or microvores (Moens \& Vincx 1997) on the windward side were mostly due to Epsilonematidae and Draconematidae, known to be adapted to extreme substrate instability. This may indicate that picking out bacteria on an individual basis may prove to be energetically favorable where microbial populations are low and/or patchy and where sediment instability is high. Conversely, higher abundances of the epigrowth feeders on the leeward side of the atoll are probably also an effect of the sediment enrichment process of this part of the atoll, where these nematodes scrape off organic coatings that can surround carbonate particles (Tietjen 1991) or directly feed on microalgae (both benthic and recently settled planktonic forms).

The hydrodynamic features that determined the significant accumulation of meiobenthic organisms, particularly nematodes, to the leeward side of Rocas Atoll probably also govern the drifting of plankton. Unfortunately, there are no data on the small-scale physical regime and plankton production at Rocas Atoll. A similar pattern of organism accumulation should indicate that the topographically controlled fronts, as suggested by Wolanski \& Hamner (1988), play a key role in the ecology of reef islands.

Acknowledgements. The Brazilian Ministry of Education (CAPES), World Wildlife Fund (WWF) and Brazilian Environmental Agency (IBAMA) funded this work. We thank Zélinha 
Brito, Dedé Bezerra, Ivo Jr and Adriana D'Amato for assisting with sampling, and Paul Somerfield for helping with nematode identification. We also thank Marcio Vianna (INPE) for the atoll satellite image, Patricia Sunye and 3 anonymous referees for their comments on the manuscript.

\section{LITERATURE CITED}

Alldredge AL, Hamner WM (1980) Recurring aggregation of zooplankton by tidal current. Estuar Coast Shelf Sci 10: $31-37$

Alongi DM (1989a) Benthic process across mixed terrigenouscarbonate sedimentary facies on the Central Barrier Reef continental shelf. Cont Shelf Res 9:629-663

Alongi DM (1989b) The role of soft-bottom benthic communities in tropical mangrove and coral reef ecosystems. Aquat Sci 1:243-280

Ambrose RF, Anderson TW (1990) Influence of an artificial reef on the surrounding infaunal community. Mar Biol $107: 41-52$

Ansari ZA, Rivonker CU, Ramani P, Parulekar AH (1991) Seagrass habitat complexity and macroinvertebrates abundance in Lakshadweep coral reef lagoons, Arabian Sea. Coral Reefs 10:127-131

Borgne R, Dandonneau Y, Lemasson L (1985) The problem of the island mass effect on chlorophyll and zooplankton standing crops around Mare (Loyalty Islands) and New Caledonia. Bull Mar Sci 37:450-459

Boucher G, Gourbault NE (1990) Sublittoral meiofauna and diversity of nematodes assemblages off Guadeloupe Islands (French West Indies). Bull Mar Sci 47:448-463

Charpy-Roubaud CJ, Charpy L (1994) Nutrients, particulate organic matter, and planktonic and benthic production of the Tikehau Atoll (Tuamotu Archipelago, French Polynesia). Atoll Res Bull 415:1-30

Clarke KR (1993) Non-parametric multivariate analyses of changes in community structure. Aust J Ecol 18:117-143

Clarke KR, Ainsworth M (1993) A method of linking multivariate community structure to environmental variables. Mar Ecol Prog Ser 92:205-219

Clarke KR, Warwick RM (1994) Changes in marine communities: an approach to statistical analyses and interpretation. Natural Environment Research Council, Plymouth

Coull BC (1988) Ecology of the marine meiofauna. In: Higgins $\mathrm{RP}$, Thiel $\mathrm{H}$ (eds) Introduction to the study of meiofauna. Smithsonian Institution Press, Washington, DC, p 18-38

Frazer TK, Lindberg WJ, Stanton GR (1991) Predation on sand dollars by gray triggerfish Ballistes capriscus in the northeastern Gulf of Mexico. Bull Mar Sci 48:159-164

Gamenick I, Giere O (1994) The microdistribution of coral sand meiofauna affected by water currents. Vie Milieu 44: 93-100

Gherardi DFM (1996) Recent carbonate sedimentation on the coralline-algal Atol das Rocas, equatorial South Atlantic, Brazil. PhD thesis, Royal Holloway University of London

Glynn PW (1997) Bioerosion and coral-reef growth: a dynamic balance. In: Bikerland C (ed) Life and death of coral reefs. Chapman \& Hall, New York, p 68-95

Gourbault NE, Warwick RM, Helleouet MN (1995) A survey of intertidal meiobenthos (especially Nematoda) in coral sandy beaches of Moorea (French Polynesia). Bull Mar Sci 57:476-488

Grelet Y (1984) Peuplements meiobenthiques et structure de la nematofaune du Golfe d'Aquaba (Jordanie- Mer Rouge). $\mathrm{PhD}$ thesis, Universite Aix Marseille II
Guzman HM, Obando VL, Cortes J (1987) Meiofauna associated with Pacific coral reef in Costa Rica. Coral Reefs 6: $107-112$

Hernández-León S (1991) Accumulation of mesozooplankton in a wake area as a causative mechanism of the 'island mass effect'. Mar Biol 109:141-147

Höflich O (1984) Climate of the South Atlantic Ocean. In: Van Loon $\mathrm{H}$ (ed) Climates of the oceans. Elsevier, Amsterdam, p 1-192

Intes A, Caillart B (1994) Environment and biota of the Tikehau Atoll (Tuamotu Archipelago, French Polynesia). Atoll Res Bull 415:1-38

Jones AR (1984) Sedimentary relationships and community structure of benthic crustacean assemblages of reefassociated sediments at Lizard Island, Great Barrier Reef. Coral Reefs 3:101-111

Matthews HR (1970) Moluscos marinhos do nordeste e norte do Brasil, II. Moluscos do Arquipélago de Fernando de Noronha. Arq Cien Mar 10:1-53

McLachlan A (1983) Sand beach ecology-a review. In: McLachlan A, Erasmus T, Junk W (eds) Sandy beaches as ecosystems. Junk, The Hague, p 321-380

Moens T, Vincx M (1997) Observations on the feeding ecology of estuarine nematodes. J Mar Biol Assoc UK 77: 211-227

Naim O (1988) Distributional patterns of mobile fauna associated with Halimeda on the Tiahura coral-reef complex (Moorea, French Polynesia). Coral Reefs 6:237-250

Narayanan B, Sivadas P (1986) Studies on the intertidal macrofauna of the sandy beach at Kavaratti Atoll (Lakshadweep). Mahasagar Bull Nat Inst Oceanogr 19:11-22

Netto SA, Warwick RM, Attrill MJ (1999) Meiobenthic and macrobenthic community structure in carbonate sediments of Rocas Atoll (NE, Brazil). Estuar Coast Shelf Sci 48:39-50

Ottmann F (1962) L'atol das Rocas dans l'Atlantique sud tropical. Rev Geol Dyn Geogr Phys 5:101-106

Palmer MA, Gust G (1985) Dispersal of meiofauna in a turbulent tidal creek. J Mar Res 43:179-210

Posey MH, Ambrose WG Jr (1994) Effects of proximity to an offshore hard-bottom reef on infaunal abundances. Mar Biol 118:745-753

Rao GC, Misra A (1983) Meiofauna from Lakshadweep, Indian Ocean. Cah Biol Mar 24:51-68

Ribas LB (1966) Estudos sobre foraminíferos bentônicos na costa do Brasil. Inst Pesq Mar 31:1-26

Rios EC (1985) Seashells of Brazil. Fundação Universidade do Rio Grande, Rio Grande, Brazil

Sale PF (1980) The ecology of fishes on coral reefs. Oceanogr Mar Biol Annu Rev 18:367-421

Salvat B, Renaud-Mornant J (1969) Étude écologique du macrobenthos et meiobenthos d'un fond sableux du lagon de Mururoa (Tuamotu- Polynésie). Cah Pac 13:303-323

Silveira ICA, Miranda LB, Brown WS (1994) On the origins of the North Brazil Current. J Geophys Res 99:22501-225012

Somerfield PJ, Warwick RM (1996) Meiofauna in marine pollution programmes. A laboratory manual. Ministry of Agriculture, Fisheries and Food, Directorate of Fisheries Research, Lowestoft

Somerfield PJ, Rees HL, Warwick RM (1995) Interrelationships in community structure between shallow-water marine meiofauna and macrofauna in relation to dredging disposal. Mar Ecol Prog Ser 127:103-112

Sorokin YI (1993) Coral reef ecology. Springer-Verlag, Berlin

Tietjen JH (1971) Population distribution and structure of the free-living nematodes of Long Island Sound. Mar Biol 43:123-136 
Tietjen JH (1991) Ecology of free-living nematodes from the continental shelf of the central Great Barrier Reef. Estuar Coast Shelf Sci 32:421-438

Tinoco IM (1967) Foraminíferos do Atol das Rocas. Trab Inst Oceanogr Univ Fed Pernamb 7/8:91-114

Villiers L (1988) Density and biomass of macro- and meiofauna in lagoon sands at Mururoa Atoll, French Polynesia. Proc 6th Int Coral Reef Symp, Australia 2:45-51

Ward AR (1975) Studies on the sublittoral free-living nematodes of Liverpool Bay. II. Influence of sediment composition on the distribution of marine nematodes. Mar Biol 30: 217-225

Warwick RM (1984) Species size distributions in marine benthic communities. Oecologia 61:32-41

Warwick RM, Buchanan JB (1970) The meiofauna off the coast of Northumberland. I. The structure of the nematode population. J Mar Biol Assoc UK 50:129-146

Warwick RM, Clarke KR (1983) Increased variability as a symptom of stress in marine communities. J Exp Mar Biol Ecol 172:215-226

Editorial responsibility: Otto Kinne (Editor),

Oldendorf/Luhe, Germany
Warwick RM, Platt HM, Clarke KR, Agard JBR, Gobin J (1990) Analysis of macrobenthic and meiobenthic community structure in relation to pollution and disturbance in Hamilton Harbour, Bermuda. J Exp Mar Biol Ecol 138:119-142

Whitlatch RB (1980) Patterns of resource utilisation and coexistence in marine intertidal deposit-feeding communities. J Mar Res 38:743-765

Wieser W (1953) Die Beziehung zwischen Mundhöhlengestalt, Ernährungsweise und Vorkommen bei freilebenden marinen Nematoden. Arkiv Zool 4:439-481

Willems KA, Vincx M, Claeys D, Vanosmael C, Heip C (1982) Meiobenthos of a sublittoral sandbank in the southern Bight of the North Sea. J Mar Biol Assoc UK 62:535-548

Wolanski E, Hamner WM (1988) Topographically controlled fronts in the ocean and their biological influence. Science 241:177-181

Yingst JY, Rhoads DC (1985) The structure of soft-bottom benthic communities in the vicinity of the Texas Flower Garden Banks, Gulf of Mexico. Estuar Coast Shelf Sci 20: 569-592

Submitted: June 25, 1998; Accepted: January 12, 1999 Proofs received from author(s): March 26, 1999 